\title{
Correction to: Practical guidance for the evaluation of disease progression and the decision to change treatment in patients with advanced gastric cancer receiving chemotherapy
}

\author{
Satoru Iwasa ${ }^{1} \cdot$ Toshihiro Kudo $^{2} \cdot$ Daisuke Takahari $^{3} \cdot$ Hiroki Hara $^{4} \cdot$ Ken Kato $^{1} \cdot$ Taroh Satoh $^{5}$
}

Published online: 22 June 2020

C Japan Society of Clinical Oncology 2020

\section{Correction to: International Journal of Clinical Oncology https://doi.org/10.1007/s10147-020-01684-z}

The article Practical guidance for the evaluation of disease progression and the decision to change treatment in patients with advanced gastric cancer receiving chemotherapy by Satoru Iwasa, Toshihiro Kudo, Daisuke Takahari, Hiroki Hara, Ken Kato, and Taroh Satoh was originally published electronically on the publisher's internet portal https://link. springer.com/article/10.1007/s10147-020-01684-z on 29 April 2020 without Open Access.

With the author(s)' decision to opt for Open Choice, the copyright of the article changed on June 10, 2020 () The Author(s) 2020 and the article is forthwith distributed under the terms of the Creative Commons Attribution 4.0 International License (https://creativecommons.org/licenses/ by/4.0/), which permits use, duplication, adaptation, distribution and reproduction in any medium or format, as long as you give appropriate credit to the original author(s) and the source, provide a link to the Creative Commons license, and indicate if changes were made.

The original article has been corrected.

Open Access This article is distributed under the terms of the Creative Commons Attribution 4.0 International License (https://creativecommons.org/licenses/by/4.0/), which permits unrestricted use, distribution, and reproduction in any medium, provided you give appropriate credit to the original author(s) and the source, provide a link to the Creative Commons license, and indicate if changes were made. Publisher's Note Springer Nature remains neutral with regard to jurisdictional claims in published maps and institutional affiliations.

Publisher's Note Springer Nature remains neutral with regard to jurisdictional claims in published maps and institutional affiliations.

The original article can be found online at https://doi.org/10.1007/ s10147-020-01684-z.

Ken Kato

kenkato@ncc.go.jp

1 Gastrointestinal Medical Oncology Division, National Cancer Center Hospital, 5-1-1, Tsukiji, Chuo-ku, Tokyo 104-0045, Japan

2 Department of Medical Oncology, Osaka International Cancer Institute, Osaka, Japan

3 Department of Gastroenterology, Cancer Institute Hospital of the Japanese Foundation for Cancer Research, Tokyo, Japan

4 Department of Gastroenterology, Saitama Cancer Center, Saitama, Japan

5 Frontier Science for Cancer and Chemotherapy, Osaka University Graduate School of Medicine, Osaka, Japan 